\title{
A study on clinical effectiveness of cosmetics containing human stem cell conditioned media
}

\author{
Hyun Jung Kim, Min Sook Jung ${ }^{*}$ (D), Yu Kyung Hur and A Hyun Jung
}

\begin{abstract}
Background: With the steadily increasing trend of functional cosmetics consumption, the public is increasingly expecting the efficacy of cosmetics, and in order to meet these consumer needs, the development of various effective raw materials, as well as products through technical convergence research, has been activating focusing on dermatology. In the Republic of Korea, much attention was paid to cosmetic raw materials using human stem cells as a new growth engine at the end of the 2000s. Accordingly, the Ministry of Food and Drug Safety implemented the Regulations on Cosmetic Safety Standards, etc., which contains the safety standards of humanderived cell and tissue culture as raw materials for cosmetics.

Methods: Twice a day, morning and evening, for 28 days, $3 \mathrm{~mL}$ of the sample provided for each subject was applied onto the entire face using an airbrush. The subjects were divided into a control group (C), an experimental group 1 (ADSC-CM 5\% group, E1) and an experimental group 2 (polymersome-containing of ADSC-CM 5\% group, E2), and there were 20 subjects in each group.
\end{abstract}

Results: Moisture content on the U-zone, melanin and erythema of lid-cheek, overall size and depth of eye wrinkles, and skin roughness of the items showed significant differences among all three groups. More specifically, E1 had a higher rate of skin improvement than C, and E2 had the highest skin improvement rate in all items: skin moisture content, transepidermal water loss (TEWL), melanin and erythema of lid-cheek, eye wrinkles, and skin roughness of lid-cheek.

Conclusions: The effectiveness of ADSC-CM was verified in all items: increases in moisture content, decrease in TEWL, and improvements of whitening and wrinkles. Moreover, the effectiveness of ADSC-CM was observed as higher in samples of polymersome-containing ADSC-CM than those of raw material ADSC-CM. Furthermore, percutaneous absorption was improved compared with previous studies on formulations in relation to polymersome at the same concentration of ADSC-CM, thereby resulting in higher effectiveness.

Trial registration: Korea National Institute for Bioethics Policy, P01-201809-13-001, Registered 06 September 2018, http://public.irb.or.kr/.

Keywords: Adipose-derived stem cell-conditioned medium, Human stem cell-conditioned media, Airbrush, Skincare device, Polymersome

\footnotetext{
*Correspondence: yunhai0540@naver.com

Dasan Skin Clinical Research Center, Dasan C\&Tech, 42, Eonju-ro 81-gil,

Gangnam-gu, Seoul 06223, Republic of Korea
}

C The Author(s). 2020 Open Access This article is distributed under the terms of the Creative Commons Attribution 4.0 International License (http://creativecommons.org/licenses/by/4.0/), which permits unrestricted use, distribution, and reproduction in any medium, provided you give appropriate credit to the original author(s) and the source, provide a link to the Creative Commons license, and indicate if changes were made. The Creative Commons Public Domain Dedication waiver (http://creativecommons.org/publicdomain/zero/1.0/) applies to the data made available in this article, unless otherwise stated. 


\section{Background}

With the steadily increasing trend of functional cosmetics consumption, the public is increasingly expecting the efficacy of cosmetics, and in order to meet these consumer needs, the development of various effective raw materials, as well as products through technical convergence research, has been activating focusing on dermatology. The number of cosmetic ingredients has reached approximately 10,000, and the development of cosmetic materials has steadily increased raw material-related technology in combination with biotechnology, composite technology, and nanotechnology. The evolution of biotechnology has also led to the development of new cosmetic ingredients and a new paradigm in cosmetic development in combination with biotechnology by Kim et al. (2019). In South Korea, much attention was paid to cosmetic raw materials using human stem cells as a new growth engine at the end of the 2000s. Accordingly, the Ministry of Food and Drug Safety implemented the Regulations on Cosmetic Safety Standards, etc., which contains the safety standards of human-derived cell and tissue culture as raw materials for cosmetics.

In the world of medical and pharmacy, medicines for intractable diseases have been continuously developed using human stem cells by Park (2013). Academically, studies on the cytotherapy effect and skin regeneration using human stem cell-derived releasing factors have been performed. For example, a study by Kim reveals that a human threedimensional (3D) skin organoid generated using induced pluripotent stem cells (iPSCs) has great potential for allogenic regenerative medicine (Kim, 2019), and a study by Lee verified the human umbilical cord blood-derived mesenchymal stem cell (hUCB-MSC) has effect on impaired wound regeneration and healing through enhanced angiogenesis (Lee, 2018). In addition, studies on the efficacy of human stem cell culture media with cosmetic materials have been steadily performed. For example, Lee conducted a study on the derivation of exosome-mimetic nanovesicles (EMNs) from human iPSCs and exploring the protective effect of EMNs on aged dermal fibroblasts (Lee, 2019), and Kim et al. performed a study on the inhibitory effects of 3D adipose tissue-derived mesenchymal stem cell-conditioned medium on immune response and an efficacy evaluation of its cream (Kim et al., 2019). Shim also conducted a study on human dermal stem/progenitor cell-derived conditioned medium ameliorates ultraviolet A-induced damage of normal human epidermal keratinocytes (Shim, 2018).

Based on the above previous studies, cosmetics containing human stem cell culture medium are cosmetic products based on the main ingredients are obtained through human stem cell culture, and can be defined as having the effect of recovering skin health, skin regeneration, and delaying aging of skin cells. Stem cells are present in various tissues in the human body, but technically, the stem cells that are being used are extracted umbilical cord blood, bone marrow, adipose tissue, etc. among adult stem cells. Among them, bone marrow stem cells have a limitation on clinical application due to low yield rate, whereas adipose tissue stem cells have relatively characterization of safe extraction, high yield of stem cells, with easy separation (Lin et al., 2005; Rodríguez et al., 2006; Tsai et al., 2004; Zuk et al., 2002, 2001). Aust et al. verified the high yield rate of human adipose-derived adult stem cells from liposuction aspirates and it demonstrated a significant negative correlation between body mass index but not the age of the donor (Aust et al., 2004). Adipose-derived stem cells conditioned medium (ADSC-CM) contains various growth factors, cytokines, bioactive components of proteins, so it is proposed as a potential ingredient for functional cosmetic products (Hibino \& Nishiyama, 2004; Krause \& Foitzik, 2006).

This study aimed at verifying the effectiveness of ADSC$\mathrm{CM}$ directly on the skin, and also suggested countermeasures for the effectiveness and improvement of the ADSC$\mathrm{CM}$. Through this, it expects to contribute greatly to the development and activation of cosmetic products containing ADSC-CM in the cosmetics industry.

\section{Methods}

This study was approved by the Institutional Review Board of the Korea National Institute for Bioethics Policy following a comprehensive review of study-related procedures (Approval number: P01-201809-13-001).

\section{Study subjects}

This study involved middle-aged women in their $30 \mathrm{~s} \sim 50 \mathrm{~s}$, who showed symptoms of hyperpigmentation (e.g., stains, freckles) and wrinkles around the eyes. They were divided into a control group (C), an experimental group 1 (ADSC-CM 5\% group, E1), and an experimental group 2 (polymersome-containing ADSC-CM 5\% group, E2), and there were 20 subjects in each group. The subjects were selected based on the guideline for efficacy evaluation of functional cosmetics suggested by the Ministry of Food and Drug Safety (MFDS) and the results of a study conducted by Lee et al. (2013). Exclusion criteria were as follows: (1) those who showed abnormal symptoms such as acute and chronic physical diseases involving the face, including facial skin diseases; (2) those with at least a 1-month history of facial application of a skincare product containing steroids; (3) those with medical histories of contact or photoallergic dermatitis caused by a topical ointment; and (4) those with sensitive or hypersensitive skin. In addition, the subjects were randomly divided into different clinical groups so as to minimize any variations in the experimental results. 
The study was conducted from September 10 to November 23, 2018. The subjects were provided with a 3$\mathrm{mL}$ research sample and instructed to apply it to their skin twice a day, once in the morning and once in the evening, over a 28-day period. They were instructed to wash their faces, smooth out their skin with a toner, and then apply the research samples on their faces. All group (C, E1, and E2) subjects applied the research samples using an airbrush left it to be absorbed without using their hands. All study subjects were monitored by the researchers and were instructed to record the daily applications in a self-care chart that was later submitted to ensure compliance with test procedures. Moreover, the subjects were fully informed that they should not use cosmetics and treatments that contained whitening or anti-wrinkle functional ingredients that could change their facial skin conditions during the research period, and they consented to do so. In addition, based on a study conducted by Han et al., the subjects were allowed to use sunblock when going outside and wear light makeup and maintain their usual skincare cosmetics or makeup habits (Han et al., 2015). However, they were instructed to not make any changes in their daily living patterns, such as exercise, because changes in living patterns could affect their skin conditions.

Regarding the measurement of facial skin conditions, a study conducted by Kim reported that at least $30 \mathrm{~min}$ of skin stabilization is necessary to measure all selected variables for the skin surface: temperature, color luminosity, transepidermal water loss (TEWL), and sebum. The study also reported that consistent measurement values could be obtained through skin stabilization regardless of environmental effects (Kim, 2007). Accordingly, skin stabilization was induced to all subjects in the present study for $30 \mathrm{~min}$ after facial wash, and all subjects underwent skin measurement. Nonetheless, skin measurement was performed at indoor temperatures between 20 and $24{ }^{\circ} \mathrm{C}$ and relative humidity levels between 40 and $60 \%$ to minimize any environmental effect based on a study conducted by Kim and Kang (2017). Additionally, the researcher instructed the subjects on how to use and manage the airbrush with hands-on training at the first visit to facilitate its use, and the spraying method was based on the principle of lymphatic massage.

\section{Research materials}

Research samples were used for this study as follows. To minimize the change in skin physiology that can be expressed according to the cosmetic formulations, the same cosmetic formulations were applied to all three groups, and only the ingredients necessary to complete the cosmetic formulations were used. The cosmetic ingredients applied to C, E1, and E2 groups are described in Table 1. The undiluted solution of ADSC-CM applied to E1 and E2 purchased from company D to prepare the research samples. The purchased ingredient listed as "human stem cell-conditioned media" in the Cosmetic Ingredient Dictionary, and the ADSC-CM was confirmed as compliant with the 'safety standards of human-derived cell and tissue culture media' published by the Ministry of Food and Drug Safety. The polymersome-containing ADSC-CM applied to the E2 is the raw material shown in Table 2, which was prepared as a polymersome by stabilizing a high content of ADSC-CM. To prepare the polymersome, acrylate/C10 30 alkyl acrylate crosspolymer and acrylate beheneth-25 methacrylate copolymer were dissolved into purified water, and then ADSC-CM (phase A), 1,2-hexanediol (phase B), and acrylate/C10-30 alkyl acrylate crosspolymer (phase C) were added in sequence and stirred using an AGI-mixer. After stirring, homogeneous mixing was performed using a homo-mixer to prepare a polymersome through high-pressure emulsification homogenizer (Microfluidizer). The research sample was manufactured as $6 \mathrm{~mL}$ ampules and was provided to the subjects to ensure easier use, which is to apply one ampule each day. The main goal of the experiment was to have the subjects use accurate volumes of the research sample.

\section{Research tools}

The airbrush (M66, Dasan C\&Tech, Korea) used for this study consisted of a spray gun, air compressor, air hose, and adapter. The configuration of the airbrush is explained in a previous study by Kim et al. (2018).

\section{Skin measurement tools}

The skin measurement tools used in this study were as follows. The SKIN-O-MAT (Corneometer, Cosmomed, Germany) was used to measure skin moisture. The Derma$\mathrm{Lab}^{\circ}$ USB test system with TEWL probe (Cortex

Table 1 Cosmetic ingredients applied to the group

\begin{tabular}{lllll}
\hline \multicolumn{1}{c}{ Ingredient } & C group & E1 group & E2 group \\
\hline Base & Water & 89.40 & 84.40 & 84.40 \\
Glycerin & 3.00 & 3.00 & 3.00 \\
Butylene Glycol & 5.00 & 5.00 & 5.00 \\
PEG-60 Hydrogenated Castor Oil & 0.50 & 0.50 & 0.50 \\
Isopropyl Myristate & 0.10 & 0.10 & 0.10 \\
1,2-Hexanediol & 2.00 & 2.00 & 2.00 \\
Active & ADSC-CM & - & 5.00 & - \\
Polymersome containing of & - & - & 5.00 \\
ADSC-CM & & & \\
Total Unit (\%) & 100 & 100 & 100 \\
\hline
\end{tabular}

Abbreviations: C Control group, E1 ADSC-CM 5\% group, E2 Polymersome containing of ADSC-CM 5\% group, ADSC-CM Adipose-derived Stem Cells Conditioned Medium 
Table 2 Cosmetic ingredients applied to polymersome containing of ADSC-CM (E2)

\begin{tabular}{ll}
\hline Ingredient & \\
\hline A & ADSC-CM \\
B & 1,2-Hexanediol \\
C & Acrylates/C10-30 Alkyl Acrylate Crosspolymer \\
& Acrylates/Beheneth-25 Methacrylate Copolymer \\
& Water \\
\hline
\end{tabular}

Technology, Denmark) was used for TEWL. Finally, Antera 3D CS (Antera 3D CS, Miravex Limited, Ireland) used for capturing images of melanin and erythema of lid-cheek, and the deepest eye wrinkles as well as for measuring the length, depth and width of wrinkles, and skin roughness.

\section{Data analysis methods}

For data analysis, SPSS 24.0 for Windows was used, and a one-way analysis of variance (ANOVA) was conducted to verify the homogeneity among the groups of study subjects before the experiment. In addition, a paired $t$ test was conducted to analyze the skin condition before and after the experiment, and a one-way ANOVA was conducted to verify significance differences of skin conditions among the groups.

\section{Results}

\section{Verification of homogeneity between groups}

Subject's baseline facial skin conditions are presented in Table 3. Because these results did not show statistically significant differences in any items, the homogeneity of the facial skin conditions among C, E1, and E2 groups was confirmed $(p>.05)$.

Subject's general characteristics are presented in Table 4. There were no significant differences between groups $\mathrm{C}, \mathrm{E} 1$, and E2 for age and job $(p>.05)$. All subjects were limited to women living in Seoul, South Korea, the homogeneity of the subject's general characteristics was confirmed.

\section{Changes in skin moisture level in each group}

Skin moisture level changes for C, E1, and E2 groups are presented in Table 5 . In the $\mathrm{T}$-zone, group $\mathrm{C}$ showed a decrease of $1.42(\mathrm{M})$ in mean moisture content, from $68.69(\mathrm{M})$ to $67.26(\mathrm{M})$, whereas group E1 showed an increase of $1.98(\mathrm{M})$ in mean moisture content, from $67.62(\mathrm{M})$ to $69.61(\mathrm{M})$ and group E2 showed an increase of $2.51(\mathrm{M})$ in mean moisture content, from 66.51(M) to 69.03(M). In the U-zone, group $C$ showed a mean moisture decrease of $2.61(\mathrm{M})$, from $75.11(\mathrm{M})$ to $72.49(\mathrm{M})$ posttreatment $(p<.05)$. Group E1 showed an increase of $0.13(\mathrm{M})$, from $72.55(\mathrm{M})$ to $72.68(\mathrm{M})$, and group E2 showed an increase of $2.96(\mathrm{M})$, from $72.96(\mathrm{M})$ to $75.93(\mathrm{M})$. This showed a statistically significant differences between groups $(p<.05)$. The moisture content of group $\mathrm{C}$ was decreased in the whole face, whereas group E1 showed an increase of moisture content in the whole face, and group E2 showed an increase of moisture content higher than E1. Moreover, there were statistically significant differences in the moisture content of U-zone between groups. Thus, it is interpreted that there is a higher increase of moisture content in the polymersome-containing ADSC-

Table 3 Verification of homogeneity between C and E1, E2 group

\begin{tabular}{|c|c|c|c|c|c|c|c|}
\hline & \multirow{2}{*}{\multicolumn{2}{|c|}{ Variable }} & \multicolumn{3}{|l|}{$\mathrm{M} \pm \mathrm{SD}$} & \multirow[t]{2}{*}{$F$} & \multirow[t]{2}{*}{$p$} \\
\hline & & & $C(n=20)$ & $\mathrm{E} 1(n=20)$ & E2 $(n=20)$ & & \\
\hline \multirow[t]{2}{*}{ Moisture } & \multicolumn{2}{|c|}{ T-zone } & $68.69 \pm 5.11$ & $67.62 \pm 6.38$ & $66.51 \pm 6.62$ & .641 & .530 \\
\hline & \multicolumn{2}{|c|}{ U-zone } & $75.11 \pm 5.73$ & $72.55 \pm 4.62$ & $72.96 \pm 5.38$ & 1.360 & .265 \\
\hline \multirow[t]{2}{*}{ TEWL } & \multicolumn{2}{|c|}{ T-zone } & $12.21 \pm 4.26$ & $11.84 \pm 2.87$ & $13.47 \pm 5.65$ & .751 & .476 \\
\hline & \multicolumn{2}{|c|}{ U-zone } & $9.50 \pm 3.94$ & $9.64 \pm 2.69$ & $11.49 \pm 4.23$ & 1.815 & .172 \\
\hline Melanin & \multicolumn{2}{|c|}{ Lid Cheek } & $34.53 \pm 2.93$ & $34.53 \pm 3.11$ & $33.29 \pm 1.37$ & 1.514 & .229 \\
\hline Erythema & \multicolumn{2}{|c|}{ Lid Cheek } & $14.12 \pm 1.99$ & $14.75 \pm 1.41$ & $14.56 \pm 1.57$ & .739 & .482 \\
\hline \multirow[t]{6}{*}{ Wrinkle } & \multirow[t]{3}{*}{ Rt. } & Overall size & $14.52 \pm 3.86$ & $13.84 \pm 4.11$ & $16.39 \pm 3.79$ & 2.239 & .116 \\
\hline & & Depth & $0.048 \pm 0.011$ & $0.042 \pm 0.013$ & $0.053 \pm 0.014$ & 2.269 & .113 \\
\hline & & Width & $1.26 \pm 0.10$ & $1.25 \pm 0.10$ & $1.29 \pm 0.21$ & 1.992 & .146 \\
\hline & \multirow[t]{3}{*}{ Lt. } & Overall size & $14.20 \pm 5.63$ & $14.29 \pm 4.30$ & $16.89 \pm 3.53$ & 3.246 & .056 \\
\hline & & Depth & $0.048 \pm 0.018$ & $0.044 \pm 0.013$ & $0.053 \pm 0.011$ & .184 & .832 \\
\hline & & Width & $1.26 \pm 0.09$ & $1.24 \pm 0.09$ & $1.24 \pm 0.12$ & .269 & .765 \\
\hline \multirow[t]{2}{*}{ Roughness } & \multicolumn{2}{|c|}{ Rt. Lid Cheek } & $5.55 \pm 0.86$ & $6.30 \pm 1.39$ & $5.59 \pm 1.17$ & 2.597 & .083 \\
\hline & \multicolumn{2}{|c|}{ Lt. Lid Cheek } & $5.63 \pm 0.73$ & $5.96 \pm 0.87$ & $5.59 \pm 1.16$ & .917 & .406 \\
\hline
\end{tabular}


Table 4 Research Subject's general characteristics

\begin{tabular}{|c|c|c|c|c|c|c|c|c|}
\hline \multirow[t]{2}{*}{ 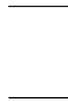 } & \multirow[t]{2}{*}{ Variable } & & \multicolumn{4}{|l|}{ Group } & \multirow[t]{2}{*}{$x^{2}$} & \multirow[t]{2}{*}{$p$} \\
\hline & & & $C(n=20)$ & E1 $(n=20)$ & E2 $(n=20)$ & Total $(n=60)$ & & \\
\hline \multirow[t]{6}{*}{ Age } & \multirow[t]{2}{*}{$30 \mathrm{~s}$} & Frequency & 0 & 2 & 0 & 2 & \multirow[t]{6}{*}{9.511} & \multirow[t]{6}{*}{.051} \\
\hline & & $\%$ of group & 0.0 & 10.0 & 0.0 & 3.3 & & \\
\hline & \multirow[t]{2}{*}{$40 \mathrm{~s}$} & Frequency & 6 & 5 & 12 & 23 & & \\
\hline & & $\%$ of group & 30.0 & 25.0 & 60.0 & 38.3 & & \\
\hline & \multirow[t]{2}{*}{$50 \mathrm{~s}$} & Frequency & 14 & 13 & 8 & 35 & & \\
\hline & & $\%$ of group & 70.0 & 65.0 & 40.0 & 58.3 & & \\
\hline \multirow[t]{12}{*}{ Job } & \multirow[t]{2}{*}{ Office worker } & Frequency & 0 & 1 & 0 & 1 & \multirow[t]{12}{*}{8.604} & \multirow[t]{12}{*}{.570} \\
\hline & & $\%$ of group & 0.0 & 5.0 & 0.0 & 1.7 & & \\
\hline & \multirow[t]{2}{*}{ Service sector } & Frequency & 1 & 1 & 0 & 2 & & \\
\hline & & $\%$ of group & 5.0 & 5.0 & 0.0 & 3.3 & & \\
\hline & \multirow[t]{2}{*}{ Professions } & Frequency & 0 & 1 & 0 & 1 & & \\
\hline & & $\%$ of group & 0.0 & 5.0 & 0.0 & 1.7 & & \\
\hline & \multirow[t]{2}{*}{ Self-employed } & Frequency & 0 & 1 & 1 & 2 & & \\
\hline & & $\%$ of group & 0.0 & 5.0 & 5.0 & 3.3 & & \\
\hline & \multirow[t]{2}{*}{ Housewife } & Frequency & 19 & 15 & 19 & 53 & & \\
\hline & & $\%$ of group & 95.0 & 75.0 & 95.0 & 88.3 & & \\
\hline & \multirow[t]{2}{*}{ Others } & Frequency & 0 & 1 & 0 & 1 & & \\
\hline & & $\%$ of group & 0.0 & 5.0 & 0.0 & 1.7 & & \\
\hline
\end{tabular}

$\mathrm{CM}$ than in the case of containing the undiluted solution of ADSC-CM.

\section{Changes in TEWL in each group}

TEWL changes for groups C, E1, and E2 are shown in Table 6. In the T-zone, TEWL was significantly increased from $12.21(\mathrm{M})$ to $15.57(\mathrm{M})$ by $3.35(\mathrm{M})$ in $\mathrm{C}$ $(p<.05)$ and from $11.84(\mathrm{M})$ to $13.58(\mathrm{M})$ by $1.74(\mathrm{M})$ in E1, whereas it was decreased from $13.47(\mathrm{M})$ to $12.49(\mathrm{M})$ by $0.98(\mathrm{M})$ in E2. In the U-zone, TEWL was significantly

Table 5 Comparison of facial Moisture (Index: AU)

\begin{tabular}{|c|c|c|c|c|c|c|}
\hline \multirow[t]{2}{*}{ Variable } & \multirow[t]{2}{*}{ Group } & \multicolumn{3}{|c|}{ Measurement $(\mathrm{M} \pm \mathrm{SD})$} & \multirow[t]{2}{*}{$F$} & \multirow[t]{2}{*}{$p$} \\
\hline & & $C(n=20)$ & E1 $(n=20)$ & $\mathrm{E} 2(n=20)$ & & \\
\hline \multirow[t]{4}{*}{ T-zone } & Before & $68.69 \pm 5.11$ & $67.62 \pm 6.38$ & $66.51 \pm 6.62$ & \multirow[t]{4}{*}{2.016} & \multirow[t]{4}{*}{.143} \\
\hline & After & $67.26 \pm 5.32$ & $69.61 \pm 7.68$ & $69.03 \pm 4.69$ & & \\
\hline & $\mathrm{tl}-\mathrm{t} 2$ & $1.42 \pm 6.15$ & $-1.98 \pm 7.64$ & $-2.51 \pm 6.30$ & & \\
\hline & $t(p)$ & $1.036(.313)$ & $-1.161(.260)$ & $-1.782(.091)$ & & \\
\hline \multirow[t]{4}{*}{ U-zone } & Before & $75.11 \pm 5.73$ & $72.55 \pm 4.62$ & $72.96 \pm 5.38$ & \multirow[t]{4}{*}{4.543} & \multirow[t]{4}{*}{$.015^{*}$} \\
\hline & After & $72.49 \pm 3.92$ & $72.68 \pm 5.88$ & $75.93 \pm 4.78$ & & \\
\hline & $\mathrm{tl}-\mathrm{t} 2$ & $2.61 \pm 5.42$ & $-0.13 \pm 5.32$ & $-2.96 \pm 6.71$ & & \\
\hline & $t(p)$ & $2.154\left(.044^{*}\right)$ & $-.114(.910)$ & $-1.977(.063)$ & & \\
\hline
\end{tabular}

Abbreviations: C Control group, E1 ADSC-CM 5\% group, E2 Polymersome containing of ADSC-CM 5\% group, ADSC-CM Adipose-derived Stem Cells Conditioned Medium, $M$ Mean, SD Standard Deviation ${ }^{*} p<.05$ increased from $9.50(\mathrm{M})$ to $12.04(\mathrm{M})$ by $2.54(\mathrm{M})$ in $\mathrm{C}$ $(p<.05)$ and from $9.64(\mathrm{M})$ to $10.01(\mathrm{M})$ by $0.37(\mathrm{M})$ in $\mathrm{E} 1$, whereas it decreased from $11.49(\mathrm{M})$ to $11.09(\mathrm{M})$ by $0.40(\mathrm{M})$ in E2. TEWL was significantly increased in the whole face in $\mathrm{C}$ as well as E1, whereas it was decreased in the entire face in E2. In summary, TEWL was decreased more when subjects applied the undiluted solution of ADSC-CM than the control sample, and it was decreased even more when subjects applied the polymersome-containing ADSC-CM.

\section{Changes in skin color luminosity in each group}

Changes in melanin of the right and left lid-cheek for groups C, E1, and E2 are presented in Table 7. Group C showed a decrease of $0.68(\mathrm{M})$, from $34.53(\mathrm{M})$ to 33.84(M), and group E1 showed a significant decrease of $2.39(\mathrm{M})$, from $34.53(\mathrm{M})$ to $32.13(\mathrm{M})(p<.001)$, and group E2 significantly decreased by $2.42(\mathrm{M})$, from $33.29(\mathrm{M})$ to $30.87(\mathrm{M})(p<.001)$. In addition, the changes in melanin of the right and left lid-cheek showed a significant difference between groups $(p<.001)$. Although the melanin of the right and left lid-cheek was decreased in all groups, melanin was decreased significantly more when subjects applied the undiluted solution of ADSC$\mathrm{CM}$ than the control sample and even more when subjects applied the polymersome-containing ADSC-CM.

Changes in erythema of the right and left lid-cheek for groups C, E1, and E2 are presented in Table 8. Erythema 
Table 6 Comparison of facial TEWL (Index: AU)

\begin{tabular}{lllllll}
\hline Variable & Group & \multicolumn{3}{l}{ Measurement $(\mathrm{M} \pm \mathrm{SD})$} & $F$ & $p$ \\
\cline { 3 - 5 } & & $\mathrm{C}(n=20)$ & $\mathrm{E} 1(n=20)$ & $\mathrm{E} 2(n=20)$ & & \\
\hline T-zone & Before & $12.21 \pm 4.26$ & $11.84 \pm 2.87$ & $13.47 \pm 5.65$ & 2.179 & .122 \\
& After & $15.57 \pm 6.22$ & $13.58 \pm 8.37$ & $12.49 \pm 4.92$ & & \\
& $\mathrm{t}_{1}-\mathrm{t}_{2}$ & $-3.35 \pm 5.97$ & $-1.74 \pm 9.24$ & $0.98 \pm 3.32$ & & \\
& $\mathrm{t}(\mathrm{p})$ & $-2.510\left(.021^{*}\right)$ & $-.843(.410)$ & $1.319(.203)$ & & \\
U-zone & Before & $9.50 \pm 3.94$ & $9.64 \pm 2.69$ & $11.49 \pm 4.23$ & 2.967 & .059 \\
& After & $12.04 \pm 3.49$ & $10.01 \pm 3.01$ & $11.09 \pm 4.32$ & & \\
& $\mathrm{t} 1$ - $\mathrm{t} 2$ & $-2.54 \pm 5.33$ & $-0.37 \pm 4.03$ & $0.40 \pm 1.51$ & & \\
& $\mathrm{t}(\mathrm{p})$ & $-2.128\left(.047^{*}\right)$ & $-.410(.686)$ & $1.188(.250)$ & & \\
\hline
\end{tabular}

Abbreviations: C Control group, E1 ADSC-CM 5\% group, E2 Polymersome containing of ADSC-CM 5\% group, ADSC-CM Adipose-derived Stem Cells Conditioned Medium, $M$ Mean, SD Standard Deviation ${ }^{*} p<.05$

significantly increased from $14.12(\mathrm{M})$ to $14.63(\mathrm{M})$ by $0.51(\mathrm{M})$ in $\mathrm{C}(p<.05)$, decreased from $14.75(\mathrm{M})$ to $14.32(\mathrm{M})$ by $0.43(\mathrm{M})$ in $\mathrm{E} 1$, and significantly decreased from $14.56(\mathrm{M})$ to $13.93(\mathrm{M})$ by $0.62(\mathrm{M})$ in E2 $(p<.05)$. In addition, the changes in erythema of the right and left lid-cheek showed a significant difference between groups $(p<.01)$. A significant increase in erythema of the right and left lid-cheeks was exhibited when subjects applied the control sample, whereas erythema was decreased significantly more when subjects applied the polymersomecontaining ADSC-CM than the undiluted solution of ADSC-CM.

\section{Changes in main wrinkles and skin roughness in each group}

The main wrinkles were selected by the researcher from thick wrinkles around the eyes of the research subjects, and the automatic setting function (that reads the same wrinkle data before and after the experiment) of the software was utilized in selecting the wrinkles through the images. The changes in the main eye wrinkles for groups C, E1, and E2 are presented in Table 9. The wrinkles around the right eye for group $\mathrm{C}$ significantly increased by $1.17(\mathrm{M})$, from $14.52(\mathrm{M})$ to $15.70(\mathrm{M})(p<.05)$, group E1 showed a significant decrease of $1.82(\mathrm{M})$, from $13.84(\mathrm{M})$ to
12.01(M) $(p<.05)$, and group E2 showed a statistically significant decrease of $2.45(\mathrm{M})$, from $16.39(\mathrm{M})$ to $13.93(\mathrm{M})(p<.001)$. In addition, the wrinkles around the left eye for group $C$ significantly increased by $1.06(\mathrm{M})$, from $14.20(\mathrm{M})$ to $15.26(\mathrm{M})$, group E1 showed a significant decrease of $1.47(\mathrm{M})$, from $14.29(\mathrm{M})$ to $12.82(\mathrm{M})(p<.05)$, and group E2 showed a statistically significant decrease of $2.67(\mathrm{M})$, from $16.89(\mathrm{M})$ to $14.22(\mathrm{M})(p<.001)$. In addition, the changes showed a significant difference between groups $(p<.001)$. All main eye wrinkles in the right and left lid-cheek were increased when subjects applied the control sample, whereas they were significantly decreased in both the right and left lid-cheek when subjects applied the undiluted solution of ADSC-CM and even more significantly decreased when subjects applied the polymersome-containing ADSC-CM.

The changes in eye wrinkle depth for groups C, E1, and E2 are presented in Table 10. The depth in wrinkles around the right eye for group $\mathrm{C}$ showed an increase of 0.003(M), from $0.048(\mathrm{M})$ to $0.051(\mathrm{M})$, group E1 showed a significant decrease of $0.005(\mathrm{M})$, from $0.042(\mathrm{M})$ to $0.036(\mathrm{M})(p<.05)$, and group E2 showed a statistically decrease of $0.007(\mathrm{M})$, from $0.053(\mathrm{M})$ to $0.046(\mathrm{M})$ $(p<.001)$. In addition, the changes showed a significant difference between groups $(p<.001)$. The depth in wrinkles around the left eye for group $C$ showed an increase of $0.002(\mathrm{M})$, from $0.048(\mathrm{M})$ to $0.050(\mathrm{M})$, group E1 showed a significant decrease of $0.005(\mathrm{M})$, from $0.044(\mathrm{M})$ to $0.039(\mathrm{M})(p<.05)$, and group E2 showed a statistically decrease of $0.007(\mathrm{M})$, from $0.053(\mathrm{M})$ to $0.046(\mathrm{M})(p<.001)$. In addition, the changes showed a significant difference between groups $(p<.01)$. All eye wrinkle depths in the right and left lid-cheek were increased when subjects applied the control sample, whereas they were decreased in both the right and left lid-cheek when subjects applied the undiluted solution of ADSC-CM and decreased, even more, when subjects applied the polymersome-containing ADSC-CM.

The changes in eye wrinkle width for groups C, E1, and E2 are presented in Table 11. The width in wrinkles around the right eye for group $\mathrm{C}$ showed an increase of

Table 7 Comparison Melanin of Lid Cheek

\begin{tabular}{|c|c|c|c|c|c|c|}
\hline \multirow[t]{2}{*}{ Variable } & \multirow[t]{2}{*}{ Group } & \multicolumn{3}{|c|}{ Measurement $(\mathrm{M} \pm \mathrm{SD})$} & \multirow[t]{2}{*}{$F$} & \multirow[t]{2}{*}{$p$} \\
\hline & & $C(n=20)$ & $\mathrm{E} 1(n=20)$ & E2 $(n=20)$ & & \\
\hline \multirow[t]{4}{*}{ Melanin } & Before & $34.53 \pm 2.93$ & $34.53 \pm 3.11$ & $33.29 \pm 1.37$ & \multirow{4}{*}{10.223} & \multirow{4}{*}{$.000^{* * *}$} \\
\hline & After & $33.84 \pm 2.47$ & $32.13 \pm 2.74$ & $30.87 \pm 1.33$ & & \\
\hline & $t_{1}-t_{2}$ & $0.68 \pm 0.40$ & $2.39 \pm 1.16$ & $2.42 \pm 1.09$ & & \\
\hline & $t(p)$ & $1.711(.103)$ & $9.188\left(.000^{* * *}\right)$ & $9.867\left(.000^{* * *}\right)$ & & \\
\hline
\end{tabular}

Abbreviations: C Control group, E1 ADSC-CM 5\% group, E2 Polymersome containing of ADSC-CM 5\% group, ADSC-CM Adipose-derived Stem Cells Conditioned Medium, $M$ Mean, SD Standard Deviation

*** $p<.001$ 
Table 8 Comparison Erythema of Lid Cheek

\begin{tabular}{|c|c|c|c|c|c|c|}
\hline \multirow[t]{2}{*}{ Variable } & \multirow[t]{2}{*}{ Group } & \multicolumn{3}{|c|}{ Measurement $(\mathrm{M} \pm \mathrm{SD})$} & \multirow[t]{2}{*}{$F$} & \multirow[t]{2}{*}{$p$} \\
\hline & & $C(n=20)$ & E1 $(n=20)$ & $\mathrm{E} 2(n=20)$ & & \\
\hline \multirow[t]{4}{*}{ Erythema } & Before & $14.12 \pm 1.99$ & $14.75 \pm 1.41$ & $14.56 \pm 1.57$ & \multirow[t]{4}{*}{7.997} & \multirow[t]{4}{*}{$.001^{*}$} \\
\hline & After & $14.63 \pm 1.77$ & $14.32 \pm 1.65$ & $13.93 \pm 1.41$ & & \\
\hline & $\mathrm{t} 1-\mathrm{t} 2$ & $-0.51 \pm 0.89$ & $0.43 \pm 1.02$ & $0.62 \pm 0.97$ & & \\
\hline & $t(p)$ & $-2.562\left(.019^{*}\right)$ & $1.901(.073)$ & $2.883\left(.010^{*}\right)$ & & \\
\hline
\end{tabular}

Abbreviations: C Control group, E1 ADSC-CM 5\% group, E2 Polymersome containing of ADSC-CM 5\% group, ADSC-CM Adipose-derived Stem Cells Conditioned Medium, $M$ Mean, $S D$ Standard Deviation

${ }^{*} p<.05,{ }^{* *} p<.01$

0.02(M), from 1.26(M) to 1.29(M), group E1 showed a decrease of $0.03(\mathrm{M})$, from $1.25(\mathrm{M})$ to $1.22(\mathrm{M})$, and group E2 showed a decrease of 0.04(M), from 1.29(M) to 1.24(M). The width in wrinkles around the left eye for group $\mathrm{C}$ showed an increase of $0.03(\mathrm{M})$, from $1.26(\mathrm{M})$ to $1.30(\mathrm{M})$, group E1 showed a decrease of $0.02(\mathrm{M})$, from 1.24(M) to 1.21(M), and group E2 showed a decrease of $0.03(\mathrm{M})$, from $1.24(\mathrm{M})$ to $1.20(\mathrm{M})$. Although significant changes were not exhibited in all items, all eye wrinkle width in the right and left lid-cheek were increased in C. However, the wrinkle width were decreased in both the right and left lid-cheek when subjects applied the undiluted solution of ADSC-CM and decreased, even more, when subjects applied the polymersome-containing ADSC-CM.

The changes in skin roughness for groups $\mathrm{C}, \mathrm{E} 1$, and E2 are presented in Table 12. Skin roughness refers to an uneven surface level in the skin, which is a representing factor in the degree of skin elasticity. Group $\mathrm{C}$ showed a significant increase of roughness in the right cheekbone of $0.54(\mathrm{M})$, from $5.55(\mathrm{M})$ to $6.09(\mathrm{M})$ $(p<.001)$, group E1 showed a significant decrease of $0.30(\mathrm{M})$, from $6.30(\mathrm{M})$ to $6.00(\mathrm{M})(p<.05)$, and group E2 showed a statistically significant decrease of $0.47(\mathrm{M})$, from $5.59(\mathrm{M})$ to $5.12(\mathrm{M})(p<.001)$. In addition, the changes showed a significant difference between groups $(p<.001)$. Group $\mathrm{C}$ showed a significant increase of roughness in the left cheekbone of $0.52(\mathrm{M})$, from
5.63(M) to 6.15(M) $(p<.001)$, group E1 showed a significant decrease of $0.09(\mathrm{M})$, from $5.96(\mathrm{M})$ to $5.86(\mathrm{M})$ $(p<.001)$, and group E2 showed a statistically significant decrease of $0.52(\mathrm{M})$, from $5.59(\mathrm{M})$ to $5.07(\mathrm{M})(p<.001)$. In addition, the changes showed a significant difference between groups $(p<.001)$. Skin roughness in the right and left cheekbone was significantly increased when subjects applied the control sample, whereas it was decreased when subjects applied the undiluted solution of ADSC-CM and decreased, even more, when subjects applied the polymersome-containing ADSC-CM.

\section{Discussion}

In a study by Kim, an undiluted solution of ADSC-CM applied a hairless mouse for 4 weeks after skin aging by a UVB irradiation-induced hairless mouse, and skin moisture content was about $23.0 \%$ higher than that of the control group, and TEWL was about $26.6 \%$ significantly lower than that of the control group $(p<.05)(\mathrm{Kim}, 2010)$. In a study by Park, applying ADSC-CM when the microneedle therapy system (MTS) was conducted $2 \mathrm{~cm}$ from the outside corners of the eyes of subjects and the experimental group significantly increased in the moisture content compared to the control group $(p<.05)$ (Park, 2013). A study by Moon reported that the moisture content increased by $11.1 \%$ before and after the experiment in a control group where a spicule moisture

Table 9 Comparison Overall size of facial wrinkle (Index: AU)

\begin{tabular}{|c|c|c|c|c|c|c|c|}
\hline \multirow[t]{2}{*}{ Variable } & \multirow[t]{2}{*}{ Group } & & \multicolumn{3}{|c|}{ 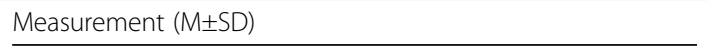 } & \multirow[t]{2}{*}{$F$} & \multirow[t]{2}{*}{$p$} \\
\hline & & & $C(n=20)$ & E1 $(n=20)$ & E2 $(n=20)$ & & \\
\hline \multirow[t]{8}{*}{ Overall size } & \multirow[t]{4}{*}{ Rt. } & Before & $14.52 \pm 3.86$ & $13.84 \pm 4.11$ & $16.39 \pm 3.79$ & \multirow[t]{4}{*}{11.213} & \multirow[t]{4}{*}{$.000^{* * *}$} \\
\hline & & After & $15.70 \pm 4.69$ & $12.01 \pm 3.59$ & $13.93 \pm 3.41$ & & \\
\hline & & $t 1-t 2$ & $-1.17 \pm 2.12$ & $1.82 \pm 3.77$ & $2.45 \pm 1.18$ & & \\
\hline & & $t(p)$ & $-2.482\left(.023^{*}\right)$ & $2.161\left(.044^{*}\right)$ & $9.257\left(.000^{* * *}\right)$ & & \\
\hline & \multirow[t]{4}{*}{ Lt. } & Before & $14.20 \pm 5.63$ & $14.29 \pm 4.30$ & $16.89 \pm 3.53$ & \multirow[t]{4}{*}{10.178} & \multirow[t]{4}{*}{$.000^{* * *}$} \\
\hline & & After & $15.26 \pm 5.98$ & $12.82 \pm 3.65$ & $14.22 \pm 3.26$ & & \\
\hline & & $t 1-t 2$ & $-1.06 \pm 2.99$ & $1.47 \pm 3.11$ & $2.67 \pm 1.66$ & & \\
\hline & & $t(p)$ & $-1.585(.129)$ & $2.115\left(.048^{*}\right)$ & $7.195\left(.000^{* * *}\right)$ & & \\
\hline
\end{tabular}

Abbreviations: C Control group, E1 ADSC-CM 5\% group, E2 Polymersome containing of ADSC-CM 5\% group, ADSC-CM Adipose-derived Stem Cells Conditioned Medium, M Mean, SD Standard Deviation

${ }^{*} p<.05,{ }^{* * *} p<.001$ 
Table 10 Comparison Depth of facial wrinkle (Index: mm)

\begin{tabular}{|c|c|c|c|c|c|c|c|}
\hline \multirow[t]{2}{*}{ Variable } & \multirow[t]{2}{*}{ Group } & & \multicolumn{3}{|c|}{ Measurement $(\mathrm{M} \pm \mathrm{SD})$} & \multirow[t]{2}{*}{$F$} & \multirow[t]{2}{*}{$p$} \\
\hline & & & $C(n=20)$ & E1 $(n=20)$ & E2 $(n=20)$ & & \\
\hline \multirow[t]{8}{*}{ Depth } & \multirow[t]{4}{*}{ Rt. } & Before & $0.048 \pm 0.011$ & $0.042 \pm 0.013$ & $0.053 \pm 0.014$ & \multirow[t]{4}{*}{5.990} & \multirow[t]{4}{*}{$.004^{* * *}$} \\
\hline & & After & $0.051 \pm 0.015$ & $0.036 \pm 0.009$ & $0.046 \pm 0.012$ & & \\
\hline & & tl-t2 & $-0.003 \pm 0.008$ & $0.005 \pm 0.011$ & $0.007 \pm 0.007$ & & \\
\hline & & $t(p)$ & $-1.604(.125)$ & $2.222\left(.039^{*}\right)$ & $4.273\left(.000^{* * *}\right)$ & & \\
\hline & \multirow[t]{4}{*}{ Lt. } & Before & $0.048 \pm 0.018$ & $0.044 \pm 0.013$ & $0.053 \pm 0.011$ & \multirow[t]{4}{*}{7.749} & \multirow[t]{4}{*}{$.001^{* *}$} \\
\hline & & After & $0.050 \pm 0.017$ & $0.039 \pm 0.011$ & $0.046 \pm 0.008$ & & \\
\hline & & $\mathrm{t} 1-\mathrm{t} 2$ & $-0.002 \pm 0.008$ & $0.005 \pm 0.011$ & $0.007 \pm 0.005$ & & \\
\hline & & $t(p)$ & $-1.205(.243)$ & $1.901(0.73)$ & $5.607\left(.000^{* * *}\right)$ & & \\
\hline
\end{tabular}

Abbreviations: C Control group, E1 ADSC-CM 5\% group, E2 Polymersome containing of ADSC-CM 5\% group, ADSC-CM Adipose-derived Stem Cells Conditioned Medium, $M$ Mean, $S D$ Standard Deviation

${ }^{*} p<.05,{ }^{* *} p<.01,{ }^{* * *} p<.001$

serum was applied to the lower cheekbone of middleaged women for 4 weeks increased by $11.1 \%$., while the moisture content significantly increased by $13.5 \%$ in an experiment group where ADSC-CM was applied $(p<.05)$. The significant increase around the eye of $12.3 \%$ compared to increase of $2.5 \%$ in the control group $(p<.05)$ (Moon, 2018). The increase in moisture content and the decrease in TEWL in the experimental groups in comparison to the control group in the present study, as shown in Tables 5 and 6 , are consistent with those in the previous studies cited. These results verified that ADSC-CM effectively increased skin moisture content and decreased TEWL.

In the study by Park in which MTS was conducted 2 $\mathrm{cm}$ from the outside corners of the eyes of subjects followed by applying ADSC-CM, the levels of melanin and erythema significantly decreased in comparison to a control group $(p<.05)$ (Park, 2013). In a study by Kim et al., the level of melanin was significantly decreased in a concentration-dependent manner at ADSC-CM 10\%,

Table 11 Comparison Width of facial wrinkle (Index: mm)

\begin{tabular}{|c|c|c|c|c|c|c|c|}
\hline \multirow[t]{2}{*}{ Variable } & \multicolumn{2}{|c|}{ Group } & \multicolumn{3}{|c|}{ Measurement $(\mathrm{M} \pm \mathrm{SD})$} & \multirow[t]{2}{*}{$F$} & \multirow[t]{2}{*}{$p$} \\
\hline & & & $C(n=20)$ & E1 $(n=20)$ & E2 $(n=20)$ & & \\
\hline \multirow[t]{8}{*}{ Width } & Rt. & Before & $1.26 \pm 0.10$ & $1.25 \pm 0.10$ & $1.29 \pm 0.21$ & 2.214 & .119 \\
\hline & & After & $1.29 \pm 0.10$ & $1.22 \pm 0.10$ & $1.24 \pm 0.27$ & & \\
\hline & & $\mathrm{t} 1-\mathrm{t} 2$ & $-0.02 \pm 0.09$ & $0.03 \pm 0.11$ & $0.04 \pm 0.14$ & & \\
\hline & & $t(p)$ & $-1.262(.222)$ & $1.206(.243)$ & $1.451(.163)$ & & \\
\hline & Lt. & Before & $1.26 \pm 0.09$ & $1.24 \pm 0.09$ & $1.24 \pm 0.12$ & 2.739 & .073 \\
\hline & & After & $1.30 \pm 0.10$ & $1.21 \pm 0.10$ & $1.20 \pm 0.16$ & & \\
\hline & & $\mathrm{t} 1-\mathrm{t} 2$ & $-0.03 \pm 0.09$ & $0.02 \pm 0.11$ & $0.03 \pm 0.11$ & & \\
\hline & & $t(p)$ & $-1.746(.097)$ & $1.114(.279)$ & $1.383(.183)$ & & \\
\hline
\end{tabular}

Abbreviations: C Control group, E1 ADSC-CM 5\% group, E2 Polymersome containing of ADSC-CM 5\% group, ADSC-CM Adipose-derived Stem Cells Conditioned Medium, $M$ Mean, SD Standard Deviation
$50 \%$, and $100 \%(p<.01)$, and the suppression effect of ADSC-CM on melanin synthesis was shown to be mediated by the downregulation of tyrosinase and tyrosinaserelated protein 1 (TRP1) (Kim et al., 2008). Furthermore, a similar level of transforming growth factor- $\beta 1$ (TGF$\beta 1$ ), which is known to suppress melanin synthesis, was detected in ADSC-CM (Kim et al., 2007; MartínezEsparza et al., 1997). A study by Lee reported that ADSC-CM suppressed the melanin synthesis of cells and significantly decreased the level of melanin at the concentrations of $50 \%$ and $100 \%(p<.01)$ (Lee, 2008). It is also reported that ADSC-CM decreased the activity of tyrosinase and significantly decreased the activity of tyrosinase at $10 \%, 50 \%$, and $100 \%$ concentrations $(p<.05, p<.01$, and $p<.01$, respectively). In addition, it is suggested that TGF- $\beta 1$ plays an important role in the suppression of the melanin synthesis of ADSC. The decreases in melanin level and erythema level in the E1 and E2 in comparison to the C, shown in Tables 7 and 8, of this study are consistent with the results of the above previous studies. These results have verified that ADSC$\mathrm{CM}$ is effective in skin whitening.

In a study by Lee, UVB was irradiated onto hairless mice to induce skin aging, followed by intradermal injection of ADSC-CM for 5 weeks, showed that a significant decrease in the number of wrinkles in the ADSC-CM-treated group $(p<.05)$ and derived the results on recovery of regular collagen structure and elastin network regarding histological change in the dermis in the ADSC-CM-treated group in comparison to the control group (Lee, 2009). Another study by Park reported that ADSCs were cultured to verify the presence of elastin in the cells and culture medium, and a higher elastin concentration was found in the culture supernatant than in the inside of the cells (Park, 2016). Elastin is one of the main components in the dermal extracellular matrix that provides skin tension and elasticity along with collagen so the elastin of ADSC-CM would contribute to skin elasticity recovery through 
Table 12 Comparison Skin Roughness of Lid Cheek

\begin{tabular}{|c|c|c|c|c|c|c|c|}
\hline \multirow[t]{2}{*}{ Variable } & \multirow[t]{2}{*}{ Group } & & \multicolumn{3}{|c|}{ Measurement $(\mathrm{M} \pm \mathrm{SD})$} & \multirow[t]{2}{*}{$F$} & \multirow[t]{2}{*}{$p$} \\
\hline & & & $C(n=20)$ & E1 $(n=20)$ & $\mathrm{E} 2(n=20)$ & & \\
\hline \multirow[t]{8}{*}{ Roughness } & \multirow[t]{4}{*}{ Rt. } & Before & $5.55 \pm 0.86$ & $6.30 \pm 1.39$ & $5.59 \pm 1.17$ & \multirow[t]{4}{*}{29.341} & \multirow[t]{4}{*}{$.000^{* * *}$} \\
\hline & & After & $6.09 \pm 0.84$ & $6.00 \pm 1.20$ & $5.12 \pm 1.15$ & & \\
\hline & & t1-t2 & $-0.54 \pm 0.49$ & $0.30 \pm 0.49$ & $0.47 \pm 0.34$ & & \\
\hline & & $t(p)$ & $-4.909\left(.000^{* * *}\right)$ & $2.711\left(.014^{*}\right)$ & $6.261\left(.000^{* * *}\right)$ & & \\
\hline & \multirow[t]{4}{*}{ Lt. } & Before & $5.63 \pm 0.73$ & $5.96 \pm 0.87$ & $5.59 \pm 1.16$ & \multirow[t]{4}{*}{16.656} & \multirow[t]{4}{*}{$.000^{* * *}$} \\
\hline & & After & $6.15 \pm 0.83$ & $5.86 \pm 1.01$ & $5.07 \pm 1.18$ & & \\
\hline & & t1-t2 & $-0.52 \pm 0.50$ & $0.09 \pm 0.77$ & $0.52 \pm 0.37$ & & \\
\hline & & $t(p)$ & $-4.632\left(.000^{* * *}\right)$ & $.532(.601)$ & $6.302\left(.000^{* * *}\right)$ & & \\
\hline
\end{tabular}

Abbreviations: C Control group, E1 ADSC-CM 5\% group, E2 Polymersome containing of ADSC-CM 5\% group, ADSC-CM Adipose-derived Stem Cells Conditioned Medium, $M$ Mean, $S D$ Standard Deviation

${ }^{*} p<.05,{ }^{* * *} p<.001$

percutaneous absorption (Mecham \& Heuser, 1991). Another study by Kim et al. reported that ADSC-CM facilitated the mRNA expression of proteins due to various growth factors that ADSC-CM contained and further increased collagen biosynthesis by increased fibroblast activity, resulting in wrinkle improvement (Kim et al., 2009). As shown in Tables 9, 10, 11 and 12 of this study, the improvement of wrinkles and elasticity of the experimental group is consistent with the results of the above previous studies. As a result, ADSC-CM proved to be effective for skin wrinkles and elasticity.

The skin of the human forms a dense structure to perform its function as an external barrier to the body, it is difficult to expect the effect of cosmetics simply by applying (Lee et al., 2010; Jang et al., 2005). The skin structure consisting of the stratum corneum, sebaceous membrane, and rein membrane of the granular layer suppresses moisture evaporation from the inside of the skin and prevents foreign matter from infiltrating the skin. However, these functions also suppress the absorption of active ingredients, Thus, mechanical methods should be used or easy chemical infiltration should be easy to do the absorption of active ingredients (Kim et al., 2018; Yoo \& Lee, 2010). Accordingly, a method to stabilize active ingredients inside the cosmetic formulation through a mixture of bioactive ingredients with lipids and the manufacturing polymer particles has been widely used in recent years (Hwang et al., 2017). Furthermore, studies on formulations using polymers, lipids, and various other materials, including nano/microencapsulation, self-assembly, and liposomes, have been conducted to achieve stabilization of various active ingredients, controlled release, and convenience of formulation and prescription. In this respect, formulations have functions of protecting active ingredients from the surrounding environment, enabling the active ingredients to be active under actual usage conditions, or releasing them at a controlled rate under specific conditions (Lim et al., 2013; Kim \& Jung, 2004; Yoo et al., 2011). The sizes of particles are manufactured through formulation studies vary widely according to experimental conditions, ranging from nanometers to tens to hundreds of micrometers (Hwang et al., 2008; Opanasopit et al., 2008).

The skin permeation of substances is largely divided into two types: absorption through skin appendages (e.g., eccrine glands, apocrine glands, sebaceous glands, and hair follicles) and absorption through the epidermis. However, skin appendages only amount to $0.1 \%$ of the total skin area, so it may be regarded as not significantly affecting the skin absorption of the substance. The absorption of substances through skin appendages accounts for $0.1 \%$ to $0.5 \%$, which is mainly an absorption path of water-soluble components and has the advantage of offering more rapid absorption than other types (Yoo \& Lee, 2010). Most of the substance absorption occurs through the epidermis, and the stratum corneum plays a role as a major barrier to skin permeation. Studies have proved that absorption through the skin is passive transport rather than active and that the stratum corneum's unique role as a selective barrier is attributed to the complex structure of $\alpha$-keratin and lipids (Choi, 1999; Yang, 2003). The substance absorption through the epidermis is then divided into two types: highly polar hydrophilic substances are the transcellular that pass directly through the cells of the stratum corneum and the lipophilic material is absorbed by a intercellular through the nonpolar fat layer. However, percutaneous absorption occurs through both paths in general.

The present study fabricated a polymer matrix that effectively stabilized ADSC-CM, which was an active ingredient, and applied a polymersome to E2. As a result, E2 had higher effectiveness in all items (i.e., moisture content of the skin, TEWL, melanin and erythema, and wrinkles and roughness) than E1 to which an undiluted solution of ADSC-CM was applied. In addition, E2 showed better improvements than E1 in melanin and erythema of cheekbone, wrinkles, and elasticity by $0.4 \%$, 
$1.4 \%, 3.7 \%$, and $5.8 \%$, respectively. Despite the same content of ADSC-CM in the E1 and E2, the difference in effectiveness can be logically attributed to the difference in formulations. Furthermore, the difference in higher effectiveness in wrinkles and elasticity than in melanin and erythema is interpreted as having greater effectiveness in the dermis at E2.

\section{Conclusion}

This study aimed at verifying the effectiveness of ADSC$\mathrm{CM}$ directly on the skin and also suggested countermeasures for effectiveness and improvement of the ADSCCM. This study involved middle-aged women in their $30 \mathrm{~s} \sim 50 \mathrm{~s}$, who showed symptoms of hyperpigmentation (e.g., stains, freckles) and wrinkles around the eyes, and the researcher provided them with research samples and let them applied $3 \mathrm{~mL}$ portion of the sample over the whole face of the subjects with an airbrush for 28 days, twice a day, once in the morning and once in the evening. They were divided into a control group $\mathrm{C}$, an experimental group E1 using ADSC-CM 5\%, and an experimental group E2 using polymersome-containing of ADSC-CM $5 \%$, and there were 20 subjects in each group.

The results showed that moisture content in the skin was decreased in $\mathrm{C}$, whereas it was increased in $\mathrm{E} 1$ and increased even more in E2. Compared to C, where TEWL was significantly increased, TEWL tended to decrease in E2.

Melanin of lid-cheek showed an increase in $\mathrm{C}$, a significant decrease in E1 $(p<.001)$, and a more significant decrease in E2 $(p<.001)$, it showed a significant difference between the groups $(p<.001)$. Erythema of lid-cheek showed a significant increase in $C(p<.05)$, a decrease in $\mathrm{E} 1$, and a more significant decrease in E2 $(p<.05)$, it showed a significant difference between the groups $(p<.01)$.

Main wrinkles around the eyes were increased in $C$ on both the right and left sides, whereas E1 showed a significant decrease $(p<.05)$, and E2 showed a more significant decrease $(p<.001)$ and it showed a significant difference between the groups $(p<.001)$. The depth of wrinkles was increased in $\mathrm{C}$ on both the right and left sides, whereas E1 showed a decrease, and E2 showed a more significant decrease $(p<.001)$, it showed a significant difference between the groups (rt., $p<.001$; lt., $p<.01$ ). The width of wrinkles was increased in $C$ on both the right and left sides, whereas E1 showed a decrease, and E2 showed a more significant decrease. Skin roughness was significantly increased in $\mathrm{C}$ on both the right and left sides $(p<.001)$, whereas $\mathrm{E} 1$ showed a decrease, and E2 showed a more significant decrease $(p<.001)$, it showed a significant difference between the groups $(p<.001)$.

Consequently, the effectiveness of ADSC-CM was verified in all items: increases in moisture content, decrease in TEWL, and improvements of whitening and wrinkles. Moreover, the effectiveness of ADSC-CM was observed as higher in samples of polymersome-containing ADSC$\mathrm{CM}$ than those of raw material ADSC-CM. Furthermore, percutaneous absorption was improved compared with previous studies on formulations in relation to polymersome at the same concentration of ADSC-CM, thereby resulting in higher effectiveness.

Until now, most studies on ADSC-CM have focused on the possible effectiveness of skin improvement by ADSC-CM through in vitro and animal tests. However, this study is significant as the effectiveness of ADSC-CM was verified through direct clinical skin tests. This study also concerns formulation methods to improve the percutaneous absorption rate in addition to the concept of the effectiveness of raw materials for skin improvements.

This results of the study will contribute to more active follow-up clinical studies to verify the effectiveness of ADSC-CM, and further suggest follow-up formulation researches to improvement and effectiveness of ADSC-CM.

\section{Abbreviations}

3D: Three dimensional; ADSC-CM: Adipose-derived stem cell-conditioned medium; EMNs: Exosome-mimetic nanovesicles; iPSCs: Induced pluripotent stem cells; MTS: Microneedle therapy system; TEWL: Transepidermal water loss

\section{Acknowledgements}

Not applicable.

\section{Authors' contributions}

HJK designed the study and wrote the manuscript. MSJ reviewed the study, wrote and edited the manuscript. YKH and $\mathrm{AHJ}$ performed the research background such as the experiments and data collection. All authors read and approved the final manuscript.

\section{Funding}

This study was performed through a joint research contract between Dasan C\&Tech and Aphrozone in 2018 and was funded by Aphrozone.

\section{Availability of data and materials \\ Not applicable.}

\section{Ethics approval and consent to participate}

This study was approved by the Institutional Review Board of the Korea National Institute for Bioethics Policy following a comprehensive review of study-related procedures (P01-201809-13-001).

\section{Consent for publication \\ Not applicable.}

\section{Competing interests}

The authors declare that they have no competing interests.

Received: 21 October 2019 Accepted: 8 January 2020

Published online: 05 March 2020

\section{References}

Aust L, Devlin B, Foster SJ, Halvorsen YDC, Hicok K, Laney TD, Sen A, Willingmyre GD, Gimble JM. Yield of human adipose-derived adult stem cells from liposuction aspirates. Cytotherapy. 2004;6(1):7-14 https://www.ncbi.nlm.nih. gov/pubmed/14985162 Accessed 2004.

Choi HK. Transdermal drug delivery system. Seoul: Shinil Company; 1999. p. 44-5. http://www.riss.kr/link?id=M7227422 Accessed 1999

Han SM, Hong IP, Woo SO, Chun SN, Han CS. The effect of cosmetic included purified bee venom on the improvement of acne. J Kor Soc Cosmetol. 2015; 21(2):288-92 http://www.riss.kr/link?id=A100486555. Accessed 2015. 
Hibino T, Nishiyama T. Role of TGF- $\beta 2$ in the human hair cycle. J Dermatol Sci. 2004;35(1):9-18 https://www.ncbi.nlm.nih.gov/pubmed/?term=hibino+ t+\%26+nishiyama+t Accessed 2004 Jun.

Hwang YK, Jeong MK, Cho SY, Park SI, Cho EC. Electrospray-assisted preparation of polymer microparticles containing water-insoluble bioactive compounds. J Soc Cosmet Scientists Korea. 2017;43(1):11-8 http://www.riss.kr/link?id=A1 03407558 Accessed 2017

Hwang YK, Jeong U, Cho EC. Production of uniform-sized polymer core-shell microcapsules by coaxial electrospraying. Langmuir. 2008;24(6):2446-51 https://pubs.acs.org/doi/10.1021/la703546f Accessed 2008.

Jang WY, Lee CR, Seo SM, Lee B, Kim MS, Khang GS, Lee HG, Lee HB. Transdermal delivery of FITC-ovalbumin with microneedle system. J Pharmaceutical Invest. 2005;35(6):403-9 http://www.koreascience.or.kr/article/JAKO200503042593 001.page Accessed 2005.

Kim GS, Kang SM. The skin safety and effects of the fermented broth of Lactobacillus rhamnosus for improving the neck skin. J Kor Soc Cosmetol. 2017;23(1):101-14 http://www.riss.kr/link?id=A103064107. Accessed 2017.

Kim HJ, Jung MS, Lim EH, Jung HS, Shin JM, Hur YK. Verification of the efficiency of the skin improvement of air brush as a homecare device using whitening cosmeceutical ingredient. J Kor Soc Cosmetol. 2018;24(2):412-21 http://www. riss.kr/link?id=A105310375. Accessed 2018.

Kim JD, Jung JH. Surface chemistry in biocompatible nanocolloidal particles. J Soc Cosmetic Scientists of Kor. 2004;30(3):295-305 http://www. koreascience.or.kr/article/JAKO200423606555446.page Accessed 2004.

Kim JE. Stabilization of facial skin physiological parameters after exposure to summer and winter climatic condition. A Master's thesis of Korea University; 2007. p. 43-4. http://www.riss.kr/link?id=T11086500. Accessed 2007

Kim KH, Lee SR, Park HS. Inhibitory effects of three dimensional adipose tissuederived mesenchymal stem cell conditioned medium on immune response and efficacy evaluation of its cream. Asian J Beauty Cosmetol. 2019;17(1):25-36 http://e-ajbc.org/m/journal/view.php?number=1136 Accessed 18 Mar 2019.

Kim SM. Effect of AdMSCs-CM Treatment on skin aging in hairless mice. A Master's thesis of Keimyung University; 2010. p. 12-3. http://www.riss.kr/ link?id=T11989964. Accessed 2010

Kim WS, Park BS, Park SH, Kim HK, Sung JH. Antiwrinkle effect of adipose-derived stem cell: activation of dermal fibroblast by secretory factors. J Dermatol Sci. 2009;(2):53, 96-102 https:/www.jdsjournal.com/article/S0923-1811(08)00253-3/ fulltext Accessed 2009

Kim WS, Park BS, Sung JH, Yang JM, Park SB, Kwak SJ, Park JS. Wound healing effect of adipose-derived stem cells: a critical role of secretory factors on human dermal fibroblasts. J Dermatol Sci. 2007;48(1):15-24 https://www. jdsjournal.com/article/S0923-1811(07)00213-7/fulltext Accessed 2007.

Kim WS, Park SH, Ahn SJ, Kim HK, Park JS, Lee GY, KIM KJ, WHANG KK, KANG SH, PARK BS, Sung JH. Whitening effect of adipose-derived stem cells: a critical role of TGF- $\beta 1$. Biol Pharmaceutical Bull. 2008;31(4):606-10 https://www.ncbi. nlm.nih.gov/pubmed/18379050 Accessed 2008.

Kim YE. Establishment of a complex skin structure via layered co-culture of keratinocytes and fibroblasts derived from induced pluripotent stem cells. A Master's thesis of Catholic University. 2019. http://www.riss.kr/link?id=T151 09028 Accessed 2019.

Krause K, Foitzik K. Biology of the hair follicle: the basics. Semin Cutan Med Surg. 2006; 25(1):2-10 https://www.ncbi.nlm.nih.gov/pubmed/16616298 Accessed 2006.

Lee CS. Effectsof hUCB-derived MSCsand small intestinal submucosa hydroge incombined radiation-wound. A doctoral thesis of Konkuk University. 2018. http://www.riss.kr/link?id=T14729461 Accessed 2018.

Lee GY. Antimelanogenic effect of adipose-derived stem cells. A doctoral thesis of Ewha Womans University; 2008. p. 9-11. http://www.riss.kr/link?id=T113 90369 Accessed 2008

Lee HL. Derivation of exosome-mimetic nanovesicles (EMNs) from human induced pluripotent stem cells and exploring protective effect of EMNs on aged dermal fibroblast. A Master's thesis of Kangwon National University. 2019. http://www.riss.kr/link?id=T15341860 Accessed 2019.

Lee JH, Moon JS, Choe TB. The effects of cosmetics containing Schizandra chinesis extracts on the middle aged women's skin. J Kor Beauty Soc. 2013; 19(4):634-41 http://devkiss.kstudy.com/thesis/thesis-view.asp?key=3162015. Accessed 2013

Lee SB. Repair effect of human adipose tissue derived stem cell on photoaged skin in albino hairless mouse. A Master's thesis of Yonsei University; 2009. p. 13-5. 21-23. http://www.riss.kr/link?id=T11565475 Accessed 2009

Lee SH, Lee SE, Hong SP, Lee HG, Park HN, Jeong SK. Skin barrier. Ryo Moon Gak. P.Co. 2010;47-65. http://www.riss.kr/link?id=M12211884. Accessed 2010.
Lim HJ, Lee JY, Kim HB, Kim DH, Shin SS. Preparation and evaluation of polymer microspheres containing Broussonetia kazinoki root Extract. J Soc Cosmet Scientists Korea. 2013;39(2):89-96 http://www.riss.kr/link?id=A100160999 Accessed 2013.

Lin TM, Tsai JL, Lin SD, Lai CS, Chang CC. Accelerated growth and prolonged lifespan of adipose tissue-derived human mesenchymal stem cells in a medium using reduced calcium and antioxidants. Stem Cells Dev. 2005;14(1): 92-102 https://www.ncbi.nlm.nih.gov/pubmed/15725748 Accessed Feb 2005

Martínez-Esparza M, Jiménez-Cervantes C, Beermann F, Aparicio P, Lozano JA, García-Borrón JC. Transforming growth factor- $\beta 1$ inhibits basal melanogenesis in B16/F10 mouse melanoma cells by increasing the rate of degradation of tyrosinase and tyrosinase-related protein-1. J Biol Chem. 1997; 272(7):3967-72 http://www.jbc.org/content/272/7/3967.long Accessed 1997.

Mecham RP, Heuser JE. The Elastic Fiber. In: Cell biology of extracellular matrix. Boston: Springer; 1991. p. 79-109. https://link.springer.com/chapter/10.1007/ 978-1-4615-3770-0_4 Accessed 1991.

Moon HJ. Effects on freeze-dried cosmetics made with spicule and stem cell culture media on the skin around eyes of middle-aged women. A Master's thesis of Konkuk University. 2018; 54-57, 68-71, 81-84. http://www.riss.kr/ link?id=T14906603 Accessed 2018

Opanasopit P, Ruktanonchai U, Suwantong O, Panomsuk S, Ngawhirunpat T, Sittisombut C, Suksamran T, Supaphol P. Electrospun poly (vinyl alcohol) fiber mats as carriers for extracts from the fruit hull of mangosteen. J Cosmetic Sci. 2008;59(3): 233-42 https://www.ncbi.n/m.nih.gov/pubmed/18528591 Accessed 2008.

Park EH. The study of the effect on middle-aged women's wrinkles around eyes by MTS and stem cell culture medium. A Master's thesis of Konkuk University; 2013. p. 29-37. http://www.riss.kr/link?id=T13244801 Accessed 2013

Park $\mathrm{IH}$. Elastin production in adiposederived stromal cell : a comparision according to the age. A Master's thesis of Seoul National University. 2016;4, 9, 18-19. http://www.riss.kr/link?id=T14226972 Accessed 2016.

Rodríguez LV, Alfonso Z, Zhang R, Leung J, Wu B, Ignarro LJ. Clonogenic multipotent stem cells in human adipose tissue differentiate into functional smooth muscle cells. Proc National Acad Sci. 2006;103(32):12167-72 https:// www.ncbi.nlm.nih.gov/pubmed/16880387 Accessed Aug 2006.

Shim JH. Human dermal stem/progenitor cell-derived conditioned medium ameliorates ultraviolet a-induced damage of normal human epidermal keratinocytes. Asian J Beauty Cosmetol. 2018;16(1):42-51 https://doi.org/10. 20402/ajbc.2017.0162 Accessed 13 Feb 2018.

Tsai MS, Lee JL, Chang YJ, Hwang SM. Isolation of human multipotent mesenchymal stem cells from second-trimester amniotic fluid using a novel two-stage culture protocol. Human Reprod. 2004;19(6):1450-6 https://www. ncbi.nlm.nih.gov/pubmed/15105397 Accessed Jun 2004.

Yang EJ. Studies on the using liposome cosmetics formulation technology and its effect on the transdermal permeation. A master's thesis of Konkuk University. 2003;39-40, 46-49, 53-57. http://www.riss.kr/link?id=T9040101 Accessed 2003.

Yoo EA, Lee HA. Rediscovery of cosmetics, vol. 41. Seoul: Sungshin Womans University press; 2010. p. 59-61. http://www.riss.kr/link?id=M12183745 Accessed 2010

Yoo JW, Doshi N, Mitragotri S. Adaptive micro and nanoparticles: temporal control over carrier properties to facilitate drug delivery. Adv Drug Delivery Rev. 2011;63:1247-56 https://www.ncbi.nlm.nih.gov/pubmed/21605607 Accessed 2011

Zuk PA, Zhu M, Ashjian P, De Ugarte DA, Huang Jl, Mizuno H, Alfonso ZC, Fraser $J K$, Benhaim P, Hedrick MH. Human adipose tissue is a source of multipotent stem cells. Mol Biol Cell. 2002;13(12):4279-95 https://www.ncbi.nlm.nih.gov/ pubmed/12475952 Accessed Dec 2002.

Zuk PA, Zhu MIN, Mizuno H, Huang J, Futrell JW, Katz AJ, Katz A, Benhaim P, Lorenz HP, Hedrick MH. Multilineage cells from human adipose tissue: implications for cell-based therapies. Tissue engineering. 2001;7(2):211-28 https://www.ncbi.nlm.nih.gov/pubmed/11304456 Accessed 2001.

\section{Publisher's Note}

Springer Nature remains neutral with regard to jurisdictional claims in published maps and institutional affiliations. 